\title{
Learning by Teaching: Can It Be Utilized to Develop Inquiry Skills?*
}

\author{
Safiye Aslan \\ Correspondence: Safiye Aslan, Faculty of Education, Aksaray University, Aksaray, Turkey. \\ Received: November 8, 2017 \\ Accepted: November 23, 2017 \\ Online Published: November 28, 2017 \\ doi:10.11114/jets.v5i12.2781 \\ URL: https://doi.org/10.11114/jets.v5i12.2781
}

\begin{abstract}
This study aims to investigate the effect of learning by teaching on inquiry skills. With its explanatory sequential design, this particular study focuses on interrogating whether learning by teaching has an effect on prospective science teachers' inquiry skills and to unveil how it does so, only if it had an effect. The current research is conducted upon 47 prospective science teachers who study in a public university in Turkey and take a course termed as Special Topics in Chemistry during the Fall term of 2016-2017 academic year. The quantitative data is gathered with an inquiry skills scale whereas the qualitative data is collected via a structured interview form. While the t-Test is used in the analysis of the quantitative data, the method of content analysis is applied in the analysis of the qualitative data. The quantitative data displays that learning by teaching has a positive effect on the prospective science teachers' inquiry skills. The qualitative data indicates that a great majority of the prospective science teachers are of the opinion that learning by teaching has an impact on inquiry skills. They think that this effect occurs under three thematic dimensions; information, thinking and affective. The findings of this particular research suggest that learning by teaching can also be a method to develop inquiry skills of prospective science teachers.
\end{abstract}

Keywords: learning by teaching, inquiry skills, prospective science teacher

\section{Introduction}

Education is the most indispensable field when it comes to dealing with social issues. That is why academic programs are often reviewed and educational revisions are made, when necessary (National Research Council [NRC], 1996; Board of Education and Discipline-Turkey [TTKB], 2005, 2006, 2013). Likewise in Turkey, educational reforms have been implemented and significant modifications have been accordingly carried out in academic programs especially for the past fifteen years (TTKB, 2005, 2006, 2013). Science teaching programs have also been modified. The 2013 modification in science teaching programs set their vision to be "to educate students to become scientifically literate" and the learning approach based on inquiry was determined to be the fundamental approach for the implementation of this vision. In this context, an improvement of inquiry skills was also aimed (TTKB, 2013). In many countries, improvement of students' inquiry skills has been encouraged in recent years (Wang, Guo \& Jou, 2015). It would be handy to investigate the process of inquiry in order to know what these inquiry skills actually are.

"Scientific inquiry refers to the diverse ways in which scientists study the natural world and propose explanations based on the evidence derived from their work. Inquiry also refers to the activities of students in which they develop knowledge and understanding of scientific ideas, as well as an understanding of how scientists study the natural world.

Inquiry is a multifaceted activity that involves making observations; posing questions; examining books and other sources of information to see what is already known; planning investigations; reviewing what is already known in light of experimental evidence; using tools to gather, analyze, and interpret data; proposing answers, explanations, and predictions; and communicating the results. Inquiry requires identification of assumptions, use of critical and logical thinking, and consideration of alternative explanations. (NRC, 1996, p.23)"

Inquiry is about reasoning especially based on data, and it is the evidence that matters for inquiry (Padilla, 2010). On the other hand, inquiry is an effective way to find out what is known and what has been learned. It helps to discover new things. Curiosity comes to the forefront in inquiry, leading to the emergence of interest in events, phenomena, people and objects, giving rise to questions and attempts to find answers to these questions. Asking questions is highly

\footnotetext{
*This study was presented as oral presentation at V. National Chemistry Education Symposium that was held in Elazig, Turkey on 7-9 Sept 2017.
} 
critical during the inquiry process. The quality of the questions asked in this process is also very important because qualified questions affect the extent to which knowledge, skills and thoughts is revealed (Tanısl1, 2013; Aslan, 2011).

The above information about inquiry also defines the skills to be applied in the process of inquiry. In the scope of this particular study, inquiry skills are investigated. Inquiry skills are of significance because they are one of the 21 st century skills and they hold to be the source for the implementation of other $21^{\text {st }}$ century skills. The $21^{\text {st }}$ century skills are generally categorized under three settings, which are learning and innovation, digital literacy, and life and career skills (Aslan, 2015; Chu, Reynolds, Tavares, Notari, \& Lee, 2016, p.8; Trilling \& Fadel, 2009; The Partnership for 21st Century Learning, 2015). When these settings of skills are considered together with their components (The Partnership for 21st Century Learning, 2015), it becomes evident that inquiry skills also need to be used for the implementation of these skills. For example, digital literacy involves components such as information literacy that involves the skills of gaining access to, interpreting, using and managing information; media literacy that involves the skills of analyzing media and creating media products; and technology literacy that involves efficient use of technology and of means and/or networks of communication in order to reach, manage, integrate, interpret and compose information (Aslan, 2015; Chu et al., 2016, p.22; Trilling \& Fadel, 2009; The Partnership for 21st Century Learning, 2015). Based on the information heretofore, it can be argued that digital literacy is based upon the inquiry of information. And this points to inquiry skills that are essential in the context of digital literacy. Individuals in the $21^{\text {st }}$ century are, therefore, expected above all to possess inquiry skills that also support the development of many other skills.

Teachers are obviously supposed to possess inquiry skills first in order for them to teach students these skills within the framework of formal education. Learning processes which teachers experience prior to professional teaching have great influence on teachers' ability to possess these skills. It is, therefore, important to make sure that teachers experience a learning process where they learn these skills before starting professional teaching. Literature reviews reveal studies that include different applications for the development of inquiry skills. Some of these studies suggest that 5E mobile inquiry learning approach (Cheng, Yang, Chang \& Kuo, 2016), full studio model (Ad, 2016), inquiry-based learning (Jeskova, Lukac, Hancova, Snajder, Gunis, Balogova \& Kires, 2016), argumentation (Horng, Lu, Chen \& Hou, 2013) and inquiry based outdoor laboratory activities (Yazgan, 2013) could be applied for the development of inquiry skills. In this current study, a different application has been employed, which is learning by teaching. Literature reviews include different applications of learning by teaching (Duran \& Topping, 2017, p.51-71; Goto \& Schneider, 2010; Norintan, 2008; Roscoe, 2014; Suvannatsiri, Santichaianant \& Murphy, 2015), one of which is the method established by Jean-Pol Martin in early 1980s for foreign language teaching (LdL "Lernen durch Lehren" in German) (Duran \& Topping, 2017, p.60; Grzega \& Schoner, 2008; Grzega, 2005; Grzega \& Klüsener, 2011; Lernen durch Lehren, 2015; Piotrowska, 2012). This particular method is considered to be a special type of peer teaching (Legenhausen, 2005) which is built upon the idea suggesting that a student instructs other students by taking the responsibility acting like a teacher (Hanbay, 2009; Serindag, 2007). It allows the student to assume the teacher's role by being in charge of an entire course, or a part of it, or of a special activity (Duran \& Topping, 2017, p.60; Grzega \& Schoner, 2008; Hanke, 2012). The philosophy "To make the student the teacher" (Skinner, 1994) lies beneath this method.

There are two ways to learn in learning by teaching: learning for teaching and learning while teaching (Aslan, 2015). Learning for teaching differs from learning for the purpose of passing an exam or a test, and it involves different mental processes (Duran, 2016). Learning for teaching others requires to put more efforts into concentrating, selecting relevant factors and presenting them as a meaningful whole, which changes the process of learning (Bargh \& Schul, 1980; trans. Duran, 2016). Learning while teaching, on the other hand, offers different opportunities, one of which is to teach with their own strategies, methods or techniques (Aslan, 2015). Explaining something to others is an important way to revise knowledge mentally, build a connection between thoughts and combine them (Duran, 2016). Another opportunity that learning while teaching offers is to build interaction between the one who teaches and the one who learns. This sort of interaction that involves asking questions and cooperating helps both the one who teaches and the one who learns learn (Aslan, 2015; Duran, 2016). It supports constructing of knowledge for both of them, as well (Duran, 2016).

Based on the comments of the prospective teachers, it was revealed in a previous study (Aslan, 2015) that learning by teaching promoted the development of inquiry skills. However, the scope of that the previous study didn't cover in detail the impact of learning by teaching on inquiry skills. Literature reviews don't reveal detailed studies on that matter, either. Studies on how to apply learning by teaching in science courses tend to be quite limited, too. This study only focuses on learning by teaching and inquiry skills, and it aims at finding out whether learning by teaching had an impact on inquiry skills or not. In this context, the research question of this study is:

- Does the method of learning by teaching applied in Special Topics in Chemistry class have an impact on the inquiry skills of science teachers? If it did, how does learning by teaching create this impact?

The method in question that was applied in this study is based upon Martin's research as indicated above (see: www.ldl). 
As Martin's applications are designed for foreign language teaching (Aslan, 2015), the latest version of that particular method, which will give opportunity to use in science course effectively, was implemented (Aslan, 2016; Kisoglu \& Aslan, 2017; Aslan, 2017). Detailed information on the steps of application of learning by teaching is shared in previous studies (Aslan, 2015; 2016; 2017; Aslan \& Gunes, 2016; Kisoglu \& Aslan, 2017).

\section{Method}

This study is structured in explanatory sequential design, which is one of the mixed research methods. In the application of that design, two phases were followed. In the first phase, quantitative data was gathered in order to find out whether learning by teaching had an impact on the inquiry skills of prospective teachers. And in the second phase, qualitative data was collected in order to discover how it affected the inquiry skills of prospective teachers. In so doing, qualitative data was recruited to facilitate the revelation of quantitative results (Cresswell \& Plano Clark, 2015, p.77-79).

\subsection{Participants}

47 prospective teachers studying in the Department of Science Teaching at a public university in Central Anatolia region of Turkey and taking the Special Topics in Chemistry class participated in this current study. 11 male and 36 female prospective teachers with ages ranging between 20 and 24 were involved. This study was carried out on 10 topics (air pollution, world's enthalpy resources, greenhouse gas, conversion of river water into drinking water, glass and ceramics, corrosion, biological processes and equilibrium, pharmacotherapy and chemistry, chemical cleaning products and their use, carbon-based materials) during the Fall semester of 2016-2017 academic year. The reason for this study to be conducted in the Special Topics in Chemistry class is that the main method applied in this particular research, which is learning by teaching, is designed for science classes and especially for classes where the relation between science, technology, society and environment is treated (Aslan, 2015; 2016). Obviously, the Special Topics in Chemistry is a class of that sort. Moreover, prospective science teachers in a previous study (Aslan, 2015) had expressed their opinions in favor of using learning by teaching in the Special Topics in Chemistry class.

\subsection{Data Collection Tools}

The quantitative data was collected by using Karademir and Saracaloglu's Likert-type "Inquiry Skills Scale" (2013). This particular scale includes expressions intended to scale prospective teachers' inquiry skills. It is composed of 14 positive articles that were categorized under three factors, i.e. acquisition of information, control of information and self-confidence. Each item is scaled by five degrees, i.e. "always-5", "usually-4", "sometimes-3", "rarely-2" and "never-1". Possible scores may range between 14 and 70. For this study, the Cronbach's Alpha coefficient is calculated to be 0.80 (pre-test) and 0.82 (post-test).

And the qualitative data was collected with a structured interview form which was designed with two questions, i.e. one closed-ended and one open-ended. While the former was restricted with three answers so as to determine whether learning by teaching had a direct impact on the inquiry skill of prospective teachers or not, the latter was intended to find out how that impact occurred. Both of these questions below were designed by taking the opinions of two experts on qualitative research:

Question 1: Do you think that learning by teaching has an impact on your inquiry skills?
( ) Yes, I do.
( ) No, I don't.
( ) I am undecided.

Question 2: If you checked off "Yes, I do." in Question 1, could you please explain how learning by teaching had an effect on your inquiry skills?

\subsection{Participant Confirmation}

Participant confirmation was requested in order to see how sufficiently the qualitative data reflected the reality (Yıldırım \& Simsek, 2013). Consequently, it was asked from the participants to read their answers on the interview form and to share their feedback in order to confirm that their answers were complete and true (Baskale, 2016; Yildirım, 2010). Incomplete or misunderstood parts were clarified immediately.

\subsection{Data Analysis}

The quantitative data was analyzed in the SPSS. As the Inquiry Skills Scale meets relevant assumptions of parametric tests while comparing the average points of the pre and post tests, the t-test is applied for dependent groups (Buyukozturk, Cokluk \& Koklu, 2011, p.166). Additionally, the eta-squared coefficient $\left(\eta^{2}\right)$ was calculated to determine the degree of difference between the pre and post-test points (Buyukozturk, 2007, p.28).

The qualitative data was analyzed with content analysis method. Content analysis is usually applied in the analysis of texts, e.g. interview printouts, diaries, and documents) (Patton, 2014, p. 453). In content analysis, many words in a text are classified into less content categories, so the text is grouped into small units. There may be one word, or a few or 
more words in one category. The words, idioms or other textual units sorted out to be in the same category are assumed to have similar meanings (Creswell \& Plano Clark, 2015, p. 221; Weber, 1990, p.12). So that the categorization process in textual analysis was consistent and credible, the coding was carried out by two different coders (Weber, 1990, p.12). While one of them was a researcher who was an expert in science teaching and experienced in qualitative data analysis, the other one was the author. The reliability of the coding was calculated with the formula suggested by Miles and Huberman (Miles \& Huberman, 2015, p. 64). It was found that the percentage of correspondence between the two coders was $81 \%$. Direct quotations from the prospective teachers' opinions were also used in order to support data interpretation. Each prospective teacher whose opinion was quoted was coded as S1, S2, S3 and so on.

\section{Results}

In this particular research, the Inquiry Skills Scale was applied prior to and after the application of learning by teaching. The average points that the prospective teachers got in the pre-test were lower than the average points that they got in the post-test. These points are compared in Table 1.

Table 1. T-Test Results

\begin{tabular}{llllllll}
\hline Measure & $\mathrm{N}$ & $\mathrm{X}$ & $\mathrm{S}$ & $\mathrm{Sd}$ & $\mathrm{t}$ & $\mathrm{p}$ & \\
\hline Pre-test & 47 & 51,12 & 6,86 & 46 & $-2,155$ & & $.036^{*}$ \\
Post-test & 47 & 54,06 & 6,96 & & & & \\
\hline
\end{tabular}

$* \mathrm{p}<.05$

The results of the analysis shared in Table 1 indicate that there is a statistically significant difference between the pre-test and post-test $(\mathrm{t}(46)=-2,155 ; \mathrm{p}=0.036)$. The eta-squared coefficient $\left(\eta^{2}\right)$ was also calculated in order to find the degree of the difference or to measure the effect size, and the result was found to be 0.09 . Eta square can take values between 0 and 1, so the Eta square values of 0.01, 0.06 and 0.14 are interpreted as small, medium and large effect sizes (Buyukozturk, 2007, p. 29). From here, it can be concluded that learning by teaching had an impact on the points that the prospective teacher got in the inquiry skills scale.

As for the first finding regarding the qualitative data, three prospective teachers think that learning by teaching doesn't have an impact on their inquiry skills whereas two prospective teachers are undecided and the rest think that learning by teaching has an impact on their inquiry skills. When it comes to the second finding about the qualitative data of the current research, it reveals how learning by teaching has an impact on the inquiry skills of the prospective teachers. The results obtained from the analysis of the data are shared in Table 2 .

Table 2. Themes and Codes

\begin{tabular}{l|l}
\hline Themes & Codes \\
\hline Information & Acquisition of information \\
& Control of information \\
\hline & Thinking more \\
& Thinking of alternative ways \\
& Questioning \\
& Asking more questions \\
& Systematic thinking \\
& Focusing \\
& Sense-making \\
& Critical thinking \\
& Clarifying of thoughts \\
\hline & Empathizing \\
& Self-confidence \\
& Valuation of others' opinions \\
& Communication \\
& Motivation \\
& Curiosity \\
& Awareness \\
\hline
\end{tabular}

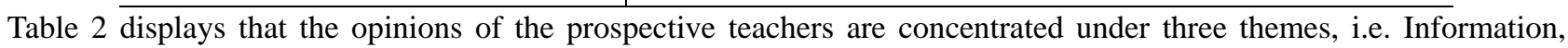
Thinking and Affectivity. The prospective teachers expressed their opinions under Information by emphasizing two codes, i.e. acquisition of information and control of information. It can be stated that acquisition of information is the code to which the participants resorted the most while sharing their opinions. Below are the examples from the opinions of the prospective teachers about Information: 
"Before learning by teaching, I used to accept the information I read as true. Now, however, I think it is necessary to resort to more sources instead of confining yourself to one source only." (S37)

"I wouldn't question, before learning by teaching, the truthfulness and validity of what I learn, and where and how I should use and understand it. I think I started to question after learning by teaching... " (S29)

"I think I learned to not accept any information as true the way it was, and to reality-check and question it..." (S20)

"Now, I contemplate on the information in the questions I come across, and I look up in books and other information sources to see if that is true or not." (S15)

"I used to take whatever I found on the internet, but I've learned that the internet alone isn't enough and it might even be untrue sometimes, so it is necessary to refer to other sources such as articles and theses." (S14)

"In the past, I could accept an argument without discussing it. Now, I even check out if the information that I teach is true or not..." (S2)

The prospective teachers expressed their opinions under Thinking by emphasizing nine codes, i.e. thinking more, thinking of alternative ways, questioning, asking more questions, systematic thinking, focusing, sense-making, critical thinking and clarifying of thoughts. Thinking More is the code to which the participants resorted the most while sharing their opinions. Below are the examples from the opinions of the prospective teachers about Thinking:

"I think I used to embrace whatever happened in the class the way it was before learning by teaching, but I am heading towards interesting questions now. And I think this has a positive impact on my inquiry skills. ” (S38)

“... It has made me think critically.” (S40)

“... I think this sort of comprehensive research has elevated my thinking skills to a higher level.” (S37)

“... learning by teaching has significantly had an impact on my skills of asking questions. ” (S32)

"I believe learning by teaching has an impact on my inquiry skills. For instance, I've started to question a matter and think of alternative, different ways about it." (S28)

“... it has helped me ask more questions as a result of a curiosity on what things are and how they happen." $(S 21)$

“... I have learned that instead of accepting anything as it is, it should be questioned.” (S20)

“... after learning by teaching, I think my inquiry skills have improved. I think it is right to reach a conclusion by questioning the reasons of everything." (S17)

"I think it has an impact, because previously when I read a text (e.g. global warming) I only memorize it without questioning, answer the questions in the exam, but I wouldn't remember anything about it after the exam. Now, I read every single sentence by sense-making it and I still have it in my memory even after weeks. I like having an idea, an opinion or an interpretation of my own and being confident in my own interpretation." (S27)

"I think I've overcome my problems of distractibility in class and shifting my thoughts easily away from the class. I find myself more concentrated now." (S6)

"After learning by teaching, I am able to do a more planned questioning now. It has helped me find ways to discover information. I think I do a more systematical thinking now." (S43)

The prospective teachers expressed their opinions under Affectivity by emphasizing seven codes, i.e. empathizing, self-confidence, valuation of others' opinions, communication, motivation, curiosity and awareness. Emphasizing is the code to which the participants resorted the most while sharing their opinions. Below are the examples from the opinions of the prospective teachers about Affectivity:

"I searched the subject fully and comprehended the parts that I hadn't understood so that I could explain them to others in the class in case they didn't understand either." (S26)

“... I learned stuff thanks to my own efforts and my self-confidence was restored. I believe I got better by making an effort to do better in teaching. I saw that I was feeling better.” (S30)

"I had the opportunity to learn subjects permanently by searching about them and teaching what I learned instead of memorizing them. I think this boosted my motivation to learn.” (S24)

"... I saw that my knowledge and expression skills were developed thanks to this method. With this method, we also held social activities, which made me discover my skills and use them. I am so happy that I both learned and taught with this method." (S39) 
“... it helped me communicate better.” (S42)

"I am now able to give the answer without hesitation if I know it. I look for different solutions. I value my friends' opinions. I pay attention to the parts which I want to learn." (S41)

\section{Discussion}

In this current research, the impact of learning by teaching on the inquiry skills of prospective teachers in the Special Topics in Chemistry class is studied. The quantitative findings indicate that learning by teaching improves the inquiry skills of prospective teachers (Table 1). The qualitative data regarding the way this improvement is achieved thanks to learning by teaching is supportive in the interpretation of the quantitative findings. The prospective teachers express their opinions on the impact of learning by teaching on their inquiry skills by concentrating their opinions under three themes, i.e. Information, Thinking and Affectivity. The prospective teachers express their opinions under Information by emphasizing that learning by teaching helps them find the ways to acquire information and teaches them that it is necessary to control information by learning the ways of controlling, which means that learning by teaching has an impact on the inquiry skills. This conclusion is also in conformity with the goal of bringing the $21^{\text {st }}$ century skills to students (Aslan, 2015; Grzega \& Schoner, 2008). Information literacy that belongs to the $21^{\text {st }}$ century skills includes acquisition of information, selection of information, interpretation and use of information (Kogce, Ozpınar, Mandacı Sahin \& Aydogan Yenmez, 2014; Trilling \& Fadel, 2009; The Partnership for 21st Century Learning, 2015). When the application steps of learning by teaching are examined, it becomes clear that the preparatory step is especially toward information literacy. It can be said that prospective teachers experience acquisition of information, valuation of information, selection of information, interpretation and use of information at the preparatory step. This step also includes the practice of asking quality questions that are worth asking about the subject. And all of these activities are related to inquiry skills (Partnership for 21st Century Skills, 2010). Learning by teaching also enables argumentation. It is also emphasized by participants in the studies on learning by teaching (Aslan, 2015; Grzega \& Schoner, 2008). Argumentation is defined to be a rational method for the questioning of information, which deserves consideration (Horng, Lu, Chen \& Hou, 2013). Prospective teachers experience the process of questioning of information with argumentation. So, it can be concluded that these experiences lead to the improvement of prospective teachers' inquiry skills.

The prospective teachers express their opinions about the impact of learning by teaching on their inquiry skills under Thinking, as well. In this context, they express that learning by teaching creates an impact on their inquiry skills by orienting them towards thinking more, thinking of alternative ways, questioning, asking more questions, systematical thinking, concentrating, sense-making, critical thinking and clarifying of thoughts. Depending on the expressions of the prospective teachers, it can be concluded that learning by teaching has an impact on the improvement of their inquiry skills by creating the opportunity for them to experience a series of skills that are triggered by questioning, such as asking questions (Delcourt \& McKinnon, 2011; Selwyn, 2014, p.268), sense-making, thinking (Delcourt \& McKinnon, 2011), searching, interpreting, communicating and taking action (Selwyn, 2014, p.268). In other words, learning by teaching encourages prospective teachers to prepare their own questions about a subject and do research in various sources so as to find answers to these questions, and in so doing, it offers them a significant opportunity to learn a special content. Moreover, it encourages prospective teachers to prepare activities for a better understanding of a subject. This makes them use their questioning skills, which leads to the improvement of their inquiry skills. Prospective teachers organize academic content, make decisions about how to deliver this content to others and operationalize it all, which might similarly contribute to the improvement of their inquiry skills. In addition, the communication between students who teach and students who learn and it is used in a wide of applications difference to which students who learn are exposed might also contribute.

The prospective teachers finally express their opinions about the impact of learning by teaching on their inquiry skills under Affectivity. In this context, they indicate that learning by teaching has an impact on their inquiry skills by contributing to the improvement of empathizing, self-confidence, valuation of others' opinions, communication, motivation, curiosity and awareness in them. The factors that prospective teachers indicate in their statements can also be considered as life skills (Dunckel, Malone \& Kadel, 2008, p.33). Additionally, it can be stated that learning by teaching offers an innovative learning environment, which provides opportunities for the improvement of students' self-confidence, social competencies and communication skills (Zygouris-Coe, 2015, p.298). So, it can be concluded that learning by teaching contributes to the improvement of their inquiry skills by offering an innovative learning environment and developing certain life skills in them. Students' behaviors in such learning environments display that learning by teaching offers a learning environment that is based on inquiry. In environments that are based on inquiry, students produce questions on their own, participate in research, take responsibility, reflect individual learning, keep asking questions so as to clarify and strengthen the truthfulness of their knowledge/comprehension, cooperate, communicate, utilize their high-level thinking skills in problem-solving and decision-making, take alternative perspectives into consideration, and demonstrate their scientific understanding and skills in various manners (Llewellyn, 2013, p.276). This current research and feedback from 
prospective teachers who participated in previous research on learning by teaching as well as experiences and observation notes regarding its application indicate that prospective teachers display such behaviors during the application of learning by teaching (Aslan, 2015; 2016; Grzega \& Schoner, 2008).

As explained above, it can be stated that learning by teaching can be applied in order to develop inquiry skills in prospective science teachers. It can be thought that different applications aiming at eliminating traditional methods and promoting the $21^{\text {th }}$ century skills in undergraduate science teaching programs should be preferred especially in these days where arguments and works towards the improvement of the quality of teachers' training (General Directorate of Teacher Training and Development-Turkey, 2017; Ozcan, 2011) are on the rise. It can be finally suggested that learning by teaching can be applied in science teaching programs so as to develop inquiry skills that are among the most important $21^{\text {st }}$ century skills and to offer a different learning experience.

\section{References}

Ad, V. N. K. (2016). The effect of full studio model on pre-service primary science teachers' conceptual understanding, social emotional learning, inquiry and science process skills: An example of fluid mechanics (Unpublished doctoral dissertation). Balıkesir University, Balıkesir.

Aslan, C. (2011). Effects of Teaching Applications for Developing Question Asking Skills on Question Forming Skills of Prospective Teachers, Education and Science, 36(160), 236-248.

Aslan, S. (2015). Is learning by teaching effective in gaining 21 st century skills? The views of pre-service science teachers. Educational Sciences: Theory \& Practice, 15(6), 1441-1457. https://doi.org/10.12738/estp.2016.1.0019

Aslan, S. (2016). The use of learning by teaching in classes where science-technology-society-environment relationships are taught: An action research. International Human and Nature Sciences: Problems and Solution Seeking Congress. Bosnia-Herzegovina: Sarajevo.

Aslan, S. (2017). The effect of learning by teaching on pre-service science teachers' attitudes towards chemistry. Journal of Turkish Science Education, 14(3), 3-17.

Baskale, H. (2016). Determination of validity, reliability and sample size in qualitative studies. Dokuz Eylul University e-Journal of Nursing Faculty, 9(1), 23-28.

Buyukozturk, S. (2007). Experimental designs. Ankara: Pegem A Publishing.

Buyukozturk, S., Cokluk, O., \& Koklu, N. (2011). Statistics for social sciences. Ankara: Pegem A Publishing.

Cheng, P., Yang, Y. C., Chang, S. G., \& Kuo, F. R. (2016). 5E mobile inquiry learning approach for enhancing learning motivation and scientific inquiry ability of university students. UEEE Transactions on Education, 59(2), 147-153. https://doi.org/10.1109/TE.2015.2467352

Chu, S. K. W., Reynolds, R. B., Tavares, N. J., Notari, M., \& Lee, C. W. Y. (2016). 21st century skills development through inquiry-based learning: From theory to practice. Singapore: Springer.

Creswell, J. W., \& Plano Clark, V. L. (2015). Designing and conducting mixed methods research (Yuksel Dede-Selcuk Besir Demir, trans. Eds.). Ankara: Anı Publishing.

Delcourt, M. A. B., \& McKinnon, J. (2011). Tools for inquiry: Improving questioning in the classroom. Learning Landscapes, 4(2), 145-159.

Dunckel, B. A., Malone, K. C., \& Kadel, N. K. (2008). Inquiry is taking Flight Through Project Butterfly WINGS. Robert E. Yager and John H. Folk (Eds.). In Exemplary science in informal education setting: Standards-based success stories (pp. 31-46). Arlington, Virginia: NSTA Press.

Duran, D., \& Topping, K. (2017). Learning by teaching: Evidence-based strategies to enhance learning in the classroom. New York, NY: Routledge.

General Directorate of Teacher Training and Development (2017). Teacher strategy document: 2017-2023. Retrieved fromhttp://oygm.meb.gov.tr/meb_iys_dosyalar/2017_06/09140719_Strateji_Belgesi_Resmi_Gazete_sonrasY_ilan. pdf

Goto, K., \& Schneider, J. (2010). Learning through teaching: Challenges and opportunities in facilitating student learning in food science and nutrition by using the inter-teaching approach. Journal of Food Science Education, 9, 31-35. https://doi.org/10.1111/j.1541-4329.2009.00087.x

Grzega, J., \& Klusener, B. (2011). Learning by teaching through polylogues: Training communication as an expert in information and knowledge societies with LdL (Lernen durch Lehren). Fachsprache: International Journal of Specialized Communication, 33, 17-35. 
Grzega, J., \& Schoner, M. (2008). The didactic model LdL (Lernen durch Lehren) as a way of preparing students for communication in a knowledge society. Journal of Education for Teaching: International Research and Pedagogy, 34(3), 167-175. https://doi.org/10.1080/02607470802212157

Hanbay, O. (2009). The effect of "learning by teaching" method based on "quantum learning" on the learning of German as a second foreign language. University of Dicle Journal of Ziya Gökalp Education Faculty, 12, 17-27.

Horng, R., Lu, P., Chen, P., \& Hou, S. (2013). The effects of argument stance on scientific knowledge inquiry skills. International Journal of Science Education, 35(16), 2784-2800. https://doi.org/10.1080/09500693.2012.671558

Jeskova, Z., Lukac, S., Hancova, M., Snajder, L., Gunis, J., Balogova, B., \& Kires, M. (2016). Efficacy of inquiry-based learning in mathematics, physics and informatics in relation to the development of students' inquiry skills. Journal of Baltic Science Education, 15(5), 559-574.

Karademir, C. A., \& Saracaloglu, A. S. (2013). The development of inquiry skills scale: Reliability and validity study. Asian Journal of Instruction, 1(2), 56-65.

Kısoglu, M., \& Aslan, S. (2017). Effect of learning by teaching on environmental knowledge, affective tendencies toward environment and responsible environmental behaviors. II. International Symposium on Social Sciences. Alanya: Alanya Alaaddin Keykubat University.

Kogce, D., Ozpinar, I., Mandacı, S. S., \& Aydogan, Y. A. (2014). Instructors' views on standards for the 21st century learners and lifelong learning. University of Dicle Journal of Ziya Gökalp Education Faculty, 22, 185-213.

Legenhausen, L. (2005). Lernen durch Lehren (LdL) in theory and practice. Retrieved from http://www.ldl.de/Material/f_/ldlintheoryandpractice.pdf

Llewellyn, D. (2013). Teaching high school science through inquiry and argumentation. Thousand Oaks, CA: Corwin Press.

Miles, M. B., \& Huberman, A. M. (2015). Qualitative data analysis. (Sadegul Akbaba Altun-Ali Ersoy, trans.). Ankara: Pegem Academy.

Norintan, A. M. (2008). Learning through teaching and sharing in the jigsaw classroom. Annals of Dentistry, 15, 71-76.

NRC, (1996). National science education standards. Washington, DC: National Academy Press.

Ozcan, M. (2011). Teacher education, qualifications and power in the information age: A reform proposal. Ankara: Turkish Education Association (TED) Economic Business.

Padilla, M. (2010). Inquiry, process skills, and thinking in science. Science and Children, 48(2), 8-9.

Partnership for 21st Century Skills (2010). 21st century knowledge and skills in educator preparation. Retrieved from http://www.p21.org/storage/documents/aacte_p21_whitepaper2010.pdf

Patton, M. Q. (2014). Qualitative research \& evaluation methods. (Mesut Butun-Selcuk Besir Demir, trans. Eds.). Ankara: Pegem A Academy.

Roscoe, R. D. (2014). Self-monitoring and knowledge-building in learning by teaching. Instructional Science, 42, 327351. https://doi.org/10.1007/s11251-013-9283-4

Selwyn, D. (2014). Why Inquiry. E. Wayne Ross (Ed.). In The social studies curriculum: Purposes, problems, and possibilities (Fourth edition) (pp. 267-288). Albany, NY: Sun Press.

Serindag, E. (2007). The effect of learning by teaching method on the teaching/learning of German as a second foreign language. Cukurova University Faculty of Education Journal, 3(33), 36-42.

Skinner, J. (1994). Learning by teaching. Zielsprache English, 2(94), 38-39.

Suvannatsiri, R., Santichaianant, K., \& Murphy, E. (2015). Learning by teaching: Undergraduate engineering students improving a community's response capability to an early warning system. European Journal of Engineering Education, 40(1), 95-113. https://doi.org/10.1080/03043797.2014.928671

Tanısl, D. (2013). Pre-service primary school mathematics teachers' questioning skills and knowledge of students in terms of pedagogical content knowledge. Education and Science, 38(169), 80-95.

The Partnership for 21st Century Learning (2015). P21 Framework definitions. Retrieved from http://www.p21.org/storage/documents/docs/P21_Framework_Definitions_New_Logo_2015.pdf

Trilling, B., \& Fadel, C. (2009). 21 st century skills learning for life in ourtimes. San Francisco: Jossey-Bass. 
TTKB (2005). Elementary science and technology course (4 and 5th classes) curriculum. Retrieved from http://ttkb.meb.gov.tr/www/ogretim- programlari/icerik/72

TTKB (2006). Elementary science and technology course (6, 7, and 8th classes) curriculum. Retrieved from http://ttkb.meb.gov.tr/www/ogretim- programlari/icerik/72

TTKB (2013). Science course (3, 4, 5, 6, 7 and 8th classes) curriculum. Retrieved from http://ttkb.meb.gov.tr/www/ogretim- programlari/icerik/72

Wang, J., Guo, D., \& Jou, M. (2015). A study on the effects of model-based inquiry pedagogy on students' inquiry skills in a virtual physics lab. Computers in Human Behaviour, 49, 658-669. https://doi.org/10.1016/j.chb.2015.01.043

Weber, R. P. (1990). Basic content analysis. Newbury Park, CA: SAGE. https://doi.org/10.4135/9781412983488

Yazgan, B. S. (2013). The effect of inquiry based outdoor laboratory activities on students' inquiry skills and their attitudes towards the environment (Unpublished doctoral dissertation). Marmara University, İstanbul.

Yıldırım, A., \& Simsek, H. (2013). Qualitative research methods in the social sciences. Ankara: Seckin Publishing.

Y1ldırım, K. (2010). Raising the quality in qualitative research. Elementary Education Online, 9(1), 79-92.

Zygouris-Coe, V. I. (2015). Teaching discipline-specific literacies in grades 6-12: Preparing students for college, career, and workforce demands. New York, NY: Routledge.

\section{Copyrights}

Copyright for this article is retained by the author(s), with first publication rights granted to the journal.

This is an open-access article distributed under the terms and conditions of the Creative Commons Attribution license which permits unrestricted use, distribution, and reproduction in any medium, provided the original work is properly cited. 